\title{
ALADINA - an unmanned research aircraft for observing vertical and horizontal distributions of ultrafine particles within the atmospheric boundary layer
}

\author{
B. Altstädter ${ }^{1}$, A. Platis ${ }^{2}$, B. Wehner ${ }^{3}$, A. Scholtz ${ }^{4}$, N. Wildmann ${ }^{2}$, M. Hermann ${ }^{3}$, R. Käthner ${ }^{3}$, H. Baars ${ }^{3}$, J. Bange ${ }^{2}$, \\ and A. Lampert ${ }^{1}$ \\ ${ }^{1}$ Institute of Flight Guidance, Technische Universität Braunschweig, Braunschweig, Germany \\ ${ }^{2}$ Center for Applied Geosciences, Eberhard Karls Universität Tübingen, Tübingen, Germany \\ ${ }^{3}$ Leibniz Institute for Tropospheric Research, Leipzig, Germany \\ ${ }^{4}$ Institute of Aerospace Systems, Technische Universität Braunschweig, Braunschweig, Germany
}

Correspondence to: B. Altstädter (b.altstaedter@tu-braunschweig.de)

Received: 1 September 2014 - Published in Atmos. Meas. Tech. Discuss.: 10 December 2014

Revised: 19 March 2015 - Accepted: 21 March 2015 - Published: 1 April 2015

\begin{abstract}
This paper presents the unmanned research aircraft Carolo P360 "ALADINA" (Application of Light-weight Aircraft for Detecting IN situ Aerosol) for investigating the horizontal and vertical distribution of ultrafine particles in the atmospheric boundary layer (ABL). It has a wingspan of $3.6 \mathrm{~m}$, a maximum take-off weight of $25 \mathrm{~kg}$ and is equipped with aerosol instrumentation and meteorological sensors. A first application of the system, together with the unmanned research aircraft MASC (Multi-Purpose Airborne Carrier) of the Eberhard Karls University of Tübingen (EKUT), is described. As small payload for ALADINA, two condensation particle counters (CPC) and one optical particle counter (OPC) were miniaturised by re-arranging the vital parts and composing them in a space-saving way in the front compartment of the airframe. The CPCs are improved concerning the lower detection threshold and the response time to less than $1.3 \mathrm{~s}$. Each system was characterised in the laboratory and calibrated with test aerosols. The CPCs are operated in this study with two different lower detection threshold diameters of 11 and $18 \mathrm{~nm}$. The amount of ultrafine particles, which is an indicator for new particle formation, is derived from the difference in number concentrations of the two CPCs $(\Delta N)$. Turbulence and thermodynamic structure of the boundary layer are described by measurements of fast meteorological sensors that are mounted at the aircraft nose. A first demonstration of ALADINA and a feasibility study were conducted in Melpitz near Leipzig, Germany, at the
\end{abstract}

Global Atmosphere Watch (GAW) station of the Leibniz Institute for Tropospheric Research (TROPOS) on 2 days in October 2013. There, various ground-based instruments are installed for long-term atmospheric monitoring. The groundbased infrastructure provides valuable additional background information to embed the flights in the continuous atmospheric context and is used for validation of the airborne results. The development of the boundary layer, derived from backscatter signals of a portable Raman lidar POLLY ${ }^{\mathrm{XT}}$, allows a quick overview of the current vertical structure of atmospheric particles. Ground-based aerosol number concentrations are consistent with the results from flights in heights of a few metres. In addition, a direct comparison of ALADINA aerosol data and ground-based aerosol data, sampling the air at the same location for more than $1 \mathrm{~h}$, shows comparable values within the range of $\pm 20 \%$. MASC was operated simultaneously with complementary flight patterns. It is equipped with the same meteorological instruments that offer the possibility to determine turbulent fluxes. Therefore, additional information about meteorological conditions was collected in the lowest part of the atmosphere. Vertical profiles up to $1000 \mathrm{~m}$ in altitude indicate a high variability with distinct layers of aerosol, especially for the small particles of a few nanometres in diameter on 1 particular day. The stratification was almost neutral and two significant aerosol layers were detected with total aerosol number concentrations up to $17000 \pm 3400 \mathrm{~cm}^{-3}$ between 180 and $220 \mathrm{~m}$ 
altitude and $14000 \pm 2800 \mathrm{~cm}^{-3}$ between 550 and $650 \mathrm{~m}$. Apart from those layers, the aerosol distribution was well mixed and reached the total number concentration of less than $8000 \pm 1600 \mathrm{~cm}^{-3}$. During another day, the distribution of the small particles in the lowermost ABL was related to the stratification, with continuously decreasing number concentrations from $16000 \pm 3200 \mathrm{~cm}^{-3}$ to a minimum of $4000 \pm 800 \mathrm{~cm}^{-3}$ at the top of the inversion at $320 \mathrm{~m}$. Above this, the total number concentration was rather constant. In the region of 500 to $600 \mathrm{~m}$ altitude, a significant difference of both CPCs was observed. This event occurred during the boundary layer development in the morning and represents a particle burst within the ABL.

\section{Introduction}

Atmospheric aerosols play an important role in our climate system (Ramanathan et al., 2001) and human health (Stieb et al., 2002; Davidson et al., 2005). The size distribution of airborne particles varies between $1 \times 10^{-3} \mu \mathrm{m}$ and $100 \mu \mathrm{m}$ in particle diameter (Baltensperger, 1997). A distinction in different modes according to the particle diameter is often used. In this article the term "ultrafine particles" refers to particles in the nucleation mode (diameter $<30 \mathrm{~nm}$ ). Due to subsequent growth, particles can reach the Aitken mode (diameter 30-100 nm). Larger particles belong to the accumulation mode (diameter $0.1-1 \mu \mathrm{m}$ ) and the coarse mode (diameter $>1 \mu \mathrm{m})$ (e.g. Kannosto et al., 2008). With increasing radius, particles have the potential to act as cloud condensation nuclei and to influence the climate system indirectly (Spracklen et al., 2008). New particle formation (NPF) is caused by nucleation (gas-to-particle conversion) and has been observed at various sites and altitudes of the Earth's system (Wiedensohler et al., 1996; Weber et al., 1997; Kulmala et al., 2004; Jaatinen et al., 2009). Formation mechanisms and growth rates have been investigated using different platforms (ground, ship and aircraft). Generally the origin and history of air masses play a key role in NPF (e.g. Sorribas et al., 2011). However, it is still not clear which meteorological situation or chemical species is most efficient for particle bursts. Homogeneous and heterogeneous nucleation requires a sufficient amount of precursor gases (Kulmala et al., 2004). The presence of non-volatile vapours is essential for the growth of freshly formed particles. Binary nucleation of water and sulphuric acid needs conditions of low temperature, high relative humidities, aerosol concentrations and a high amount of sulphuric acid (Doyle, 1961; Raes et. al, 1992; Kulmala et al., 2000).

The atmospheric boundary layer (ABL) is the lowest part of the troposphere and is influenced by the exchange of heat, water vapour, trace gases and aerosols with the surface. Its properties determine the formation, growth and processing of airborne particles. In the $\mathrm{ABL}$, stable conditions are frequent during night-time and often coupled with a strong temperature inversion. Inversions prevent interactions of air masses with the free troposphere so that various horizontal layers of aerosols can coexist without vertical mixing. Knowledge of the influence of atmospheric boundary layer development and turbulent mixing on particle bursts is still lacking. Bigg (1997) and Nilsson et al. (2001) assumed nucleation due to turbulent mixing processes. Nilsson et al. (2001) concluded entrainment and convection as a cause for nucleation. Stratmann et al. (2003) investigated particle burst events in the residual layer (RL) and mixed layer. Moreover, NPF was observed with increasing turbulence in the RL by Wehner et al. (2010). Enhanced concentrations of ultrafine particles in the morning can be trapped vertically due to the stable boundary layer. During daytime, convection leads to turbulent mixing, and vertical profiles of aerosol concentrations demonstrate a homogeneous distribution. In addition, Siebert et al. (2004) presented new particle formation near the inversion layer of the ABL. Another study investigated new particle formation related to a nocturnal low-level jet, measured with the system ACTOS (Airborne Cloud Turbulence Observation System), installed bellow a tethered-balloon (Siebert et al., 2007). In this study, NPF events were observed in connection with an increase of $\mathrm{SO}_{2}$ concentrations in the lower part of the jet. However, more information about sources and formation processes of new particle formation within the atmospheric boundary layer is essential to understand the complex developments of aerosols in the atmosphere and has to be implemented in models (Boy et al., 2006). The vertical aerosol distribution is strongly related to the synoptic conditions, the evolution of the ABL (e.g. Harnisch et al., 2009), the thermodynamic structures and the atmospheric turbulence (Boy et al., 2003). As different processes can be involved in NPF, and subsequent growth out of the gas phase, repeated vertical profiles of the aerosol concentration and size distribution are needed to elucidate the origin of NPF (Hellmuth, 2006). The variability of small particles over large distances has been analysed by networks of ground-based measurement stations (Vana et al., 2004; Wehner et al., 2007) and additionally by aircraft (O'Dowd et al., 2009). In summary, there are many indications that NPF starts in a vertically confined layer around the altitude of the inversion. Nevertheless, the existing data set is still poor and so far a systematic analysis was not possible due to a missing suitable measurement system. Distributions from the surface up to the free troposphere can be measured by in situ instruments, e.g. towers, tethered balloon systems and radiosondes. Manned aircraft measurements offer information about the vertical distribution of aerosols for larger scales and higher altitudes. Airborne measurements investigated the large-scale variability of the particle concentrations along air mass trajectories (O'Dowd et al., 2009). Here, in particular, is a lack of detailed measurements of the small-scale vertical and horizontal variability which are recommended for the implementation of NPF in models (Boy et al., 2006). 
Unmanned aerial systems (UAS), also called remotely piloted aircraft systems, offer a lot of advantages as research platforms and have become increasingly important in the last decade. The miniaturisation of electronic components allows the implementation of three-dimensional GPS (Global Positioning System) and IMU (inertial measurement unit) to record accurate position, attitude, time and speed of the aircraft (van den Kroonenberg et al., 2008). Autopilot control offers the possibility to fly with low cruising speed at constant heights in order to derive turbulent fluxes (e.g. Thomas et al., 2012). Further advantages of small unmanned research aircraft are minimal logistical requirements (e.g. no airport necessary), potentially lower costs compared to manned aircraft, high flexibility, the possibility to investigate atmospheric parameters at small scales and low altitudes and the potential for application in regions that are too dangerous for manned aircraft. Some applications, with regard to sample atmospheric aerosol by a UAS, can be seen e.g. in Clarke et al. (2002), who have tested, among other instruments, a "mini optical particle counter (OPC)" (Met One 237A) for in situ aircraft measurements. Bates et al. (2013) investigated the vertical distribution of atmospheric aerosols in the Arctic (Svalbard, Norway) by means of the UAS Manta. The aerosol package contained in particular a three-wavelength absorption photometer for detecting the optical properties of black carbon (BC). Tropospheric ozone, which is, besides its role as greenhouse gas, an important precursor for new particle formation, was investigated by Illingworth et al. (2014). In this study, the variability of ozone concentrations within the ABL was measured by an electrochemical concentration cell ozonesonde, equipped on a Skywalker UAS. Corrigan et al. (2008) presented, as part of the extensive Maldives Autonomous Unmanned Aerial Vehicle campaign, vertical profiles of aerosols and $\mathrm{BC}$ measured with the payload installed in the UAS Manta. The aerosol payload contained a total particle counter (TSI, model 3007) with a threshold diameter of $10 \mathrm{~nm}$, an optical particle counter (Met One, model 9722) and a three-wavelength absorption photometer (adapted from Magee Scientific AE-31). The system is similar to ALADINA (Application of Light-weight Aircraft for Detecting IN situ Aerosol), but the authors of this P360 "ALADINA" study have a clear focus on the formation of ultrafine particles relating to atmospheric processes. With ALADINA, an efficient and flexible tool is created to study the small-scale horizontal and vertical distribution and variability of aerosols in the size range of $11 \mathrm{~nm}$ to $10 \mu \mathrm{m}$. Complementary to groundbased monitoring instruments, it provides in situ measurements of aerosol and meteorological properties at variable altitudes up to $1000 \mathrm{~m}$. ALADINA thus can fill the spatial gap in the atmospheric boundary layer measurements between ground-based instruments, LIDAR (LIght Detection And Ranging) column measurements that usually cover an altitude range above $300 \mathrm{~m}$ and measurements at higher altitudes with larger extent provided by manned aircraft.

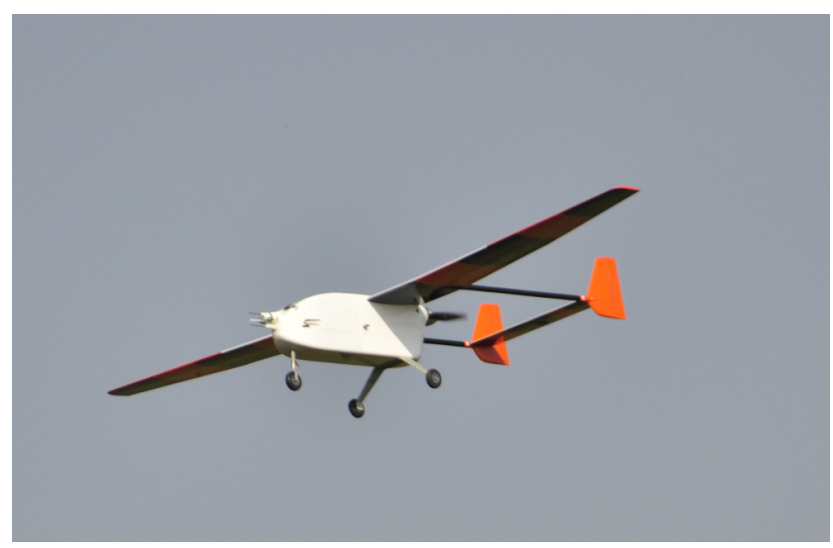

Figure 1. ALADINA during a measurement flight.

This article presents the unmanned research aircraft ALADINA and the results of a first application. In Sect. 2, the applied measurement systems and methodology are introduced: the airframe Carolo P360, the ALADINA aerosol payload and its calibration, the meteorological sensors and the data acquisition. Furthermore, the aircraft MASC (MultiPurpose Airborne Carrier) is described. In Sect. 3, the measurement site Melpitz and the first field application are discussed in detail. Finally, a summary of the article and a conclusion concerning the new device ALADINA for aerosol research is provided in Sect. 4 .

\section{Measurement systems and methodology}

\subsection{Unmanned research aircraft Carolo P360 "ALADINA"}

The Carolo P360 is a pusher aircraft with a large payload bay $(0.35 \times 0.31 \times 0.19 \mathrm{~m})$ to carry various instrumentation. In the case of ALADINA (Fig. 1), the P360 is equipped with meteorological sensors and aerosol instrumentation. The aircraft family "Carolo P360" was developed at the Institute of Aerospace Systems at the Technische Universität Braunschweig (Scholtz et al., 2011). It has a wingspan of $3.6 \mathrm{~m}$ and a maximum take-off weight of $25 \mathrm{~kg}$. Safe operation is given by wind speeds less than $15 \mathrm{~m} \mathrm{~s}^{-1}$ and below cloud base. The cruising speed is typically 25 to $28 \mathrm{~m} \mathrm{~s}^{-1}$. An electrical propulsion system allows a flight endurance of approximately $40 \mathrm{~min}$. After $20 \mathrm{~min}$ for exchanging battery packs and saving data, the P360 can be operated again. Flight preparation includes charging the batteries, checking the whole system and saving data. A combustion engine is generally compatible with the P360 but is not used for ALADINA in order to reduce vibrations that might disturb the measurements of turbulent fluxes and to make sure that the aerosol sensors are not contaminated with the exhaust from ALADINA. Another advantage of the electrically operated system is keeping the centre of gravity constant. This allows 


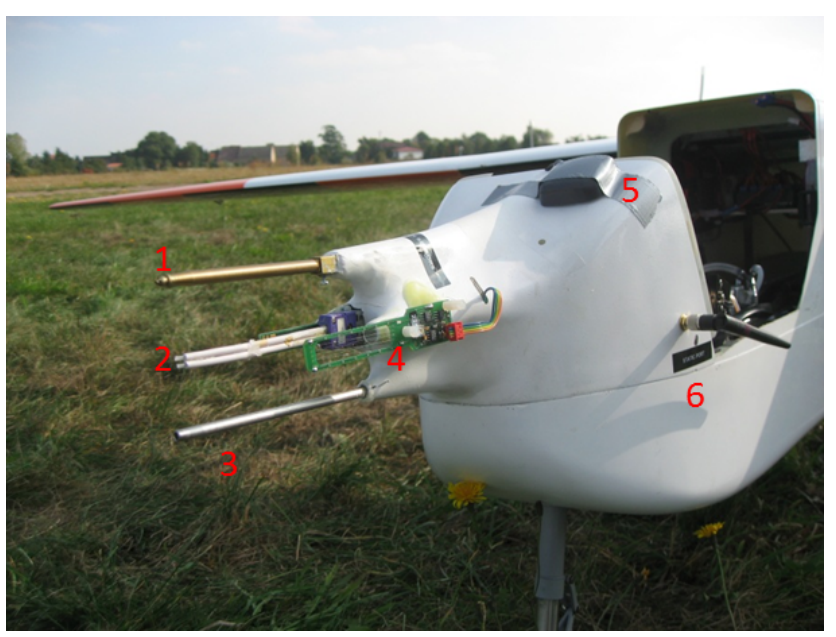

Figure 2. The meteorological payload is mounted at the tip of the aircraft. The components are (1) five-hole probe, (2) temperature sensor (thermocouple) and humidity sensor P14 Rapid, (3) aerosol inlet, (4) fine wire platinum resistance thermometer, (5) GPS antenna and (6) telemetry antenna for real-time data transfer.

a precise calibration of the angle of attack (van den Kroonenberg et al., 2008) that is necessary for determining accurate wind data. The battery system for the electric motor consists of two battery packs with a combined capacity of about $20 \mathrm{Ah}$. No additional equipment like a winch system or catapult is necessary for take-off. A landing gear, fixed on the lower fuselage, offers an easy handling during take-off and landing on flat surfaces (e.g. grass, asphalt or snow). The airfield requires a dimension of approximately $60 \mathrm{~m} \times 25 \mathrm{~m}$ depending on wind conditions and the pilot's experience.

The meteorological sensors and an aerosol inlet are installed at the front of aircraft nose (Fig. 2). The miniaturised aerosol instrumentation is located in the modular payload bay (Fig. 3) of the aircraft. Also, the data acquisition of ALADINA is installed in the front part and allows real-time data transfer by a telemetry downlink. The total weight of the payload is $<2.8 \mathrm{~kg}$. Every electric subsystem like propulsion, autopilot combined with a manual control unit and aerosol instrumentation, together with meteorology measurement unit, GPS and IMU, has its own power supply and can be operated alone. ALADINA can be flown automatically by the autopilot ROCS (Research Onboard Computing System) that is provided by the Institute of Flight Mechanics and Control of the University of Stuttgart. More information can be found in Haala et al. (2011) and Wildmann et al. (2014a). This autopilot allows precise measurement flights in the lower ABL over larger distances. ALADINA follows the flight pattern which was sent to the aircraft before take-off by the ground station. Within the telemetry range of $1.5 \mathrm{~km}$, the ground staff are able to follow and monitor the position, attitude and airspeed of the aircraft. Changes of the waypoints and altitudes are possible within that range and during flights.

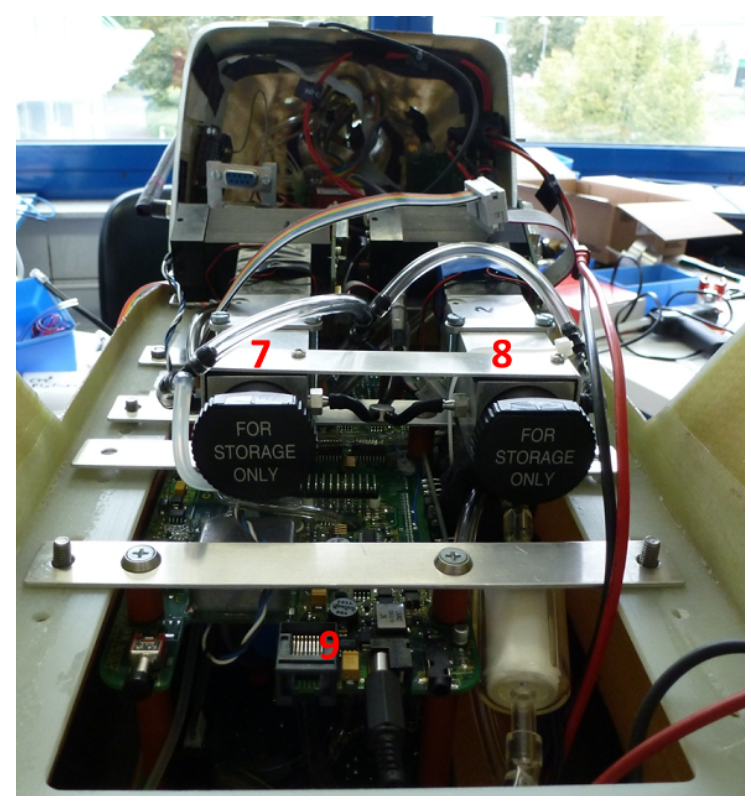

Figure 3. The aerosol payload is installed in the front compartment of the air plane and consists of two condensation particle counters (7 and 8) and one optical particle counter (9) that is mounted underneath (view from the rear). The first $\mathrm{CPC} 1$ (7) detects particle number concentrations in a particle diameter range of $11 \mathrm{~nm}$ to $2 \mu \mathrm{m}$. The second CPC2 (8) measures the particle number concentrations between $18 \mathrm{~nm}$ and $2 \mu \mathrm{m}$.

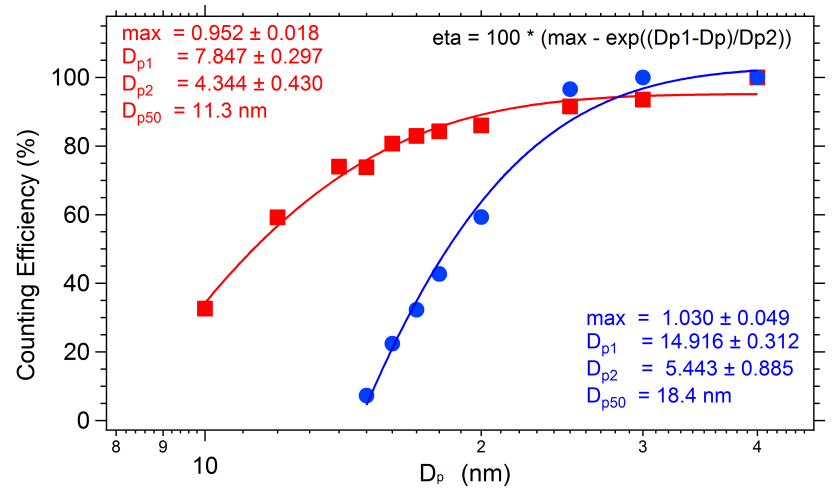

Figure 4. The counting efficiency of the CPCs with different detection limits (11 and $18 \mathrm{~nm}$ respectively) depending on the particle diameter $\left(D_{\mathrm{p}}\right)$. The difference between the readings of the two CPCs provides the number concentration of ultrafine particles that are an indicator for new particle formation.

In principle, ALADINA is able to operate at night equipped with the appropriate lighting upon permission of the local civil aviation authorities (CAA). Operation in precipitation is currently not possible since ALADINA measurement electronics are not rainproof. In addition, operation in clouds is not allowed by the CAA. 


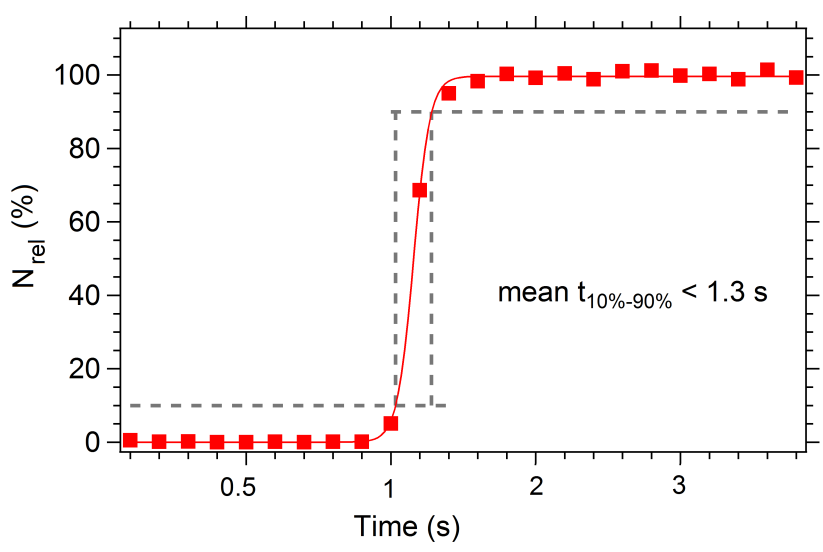

Figure 5. The mean response time of $1.3 \mathrm{~s}$ was initiated by a high increase in number concentration that is represented by the relative number concentration $\left(N_{\text {rel }}\right)$ during a calibration in the laboratory.

\subsection{Aerosol instrumentation}

The aerosol instrumentation (Fig. 3) consists of three particle counters and a stainless steel tube with rounded inlet lips as aerosol inlet (Fig. 2, no. 3). One OPC (model GT-526, Met One Instruments Inc., Washington, USA) and two condensation particle counters (CPCs) (model 3007, TSI Inc., St Paul, USA) were miniaturised and calibrated in the laboratory at the Leibniz Institute for Tropospheric Research. Weight reduction of the instruments was realised by removing housings, internal batteries and displays of the OPC and the CPCs, as well as using only one pump for both CPCs. The CPCs were calibrated in the laboratory with silver particles of different sizes (Hermann and Wiedensohler, 2001). The counting efficiency and response time of the newly designed CPCs are displayed in Figs. 4 and 5. While the counting efficiency curves show a typical behaviour, the response time is surprisingly fast with $<1.3 \mathrm{~s}$ for $t_{10-90 \%}$ compared to the approximate response time of $9 \mathrm{~s}$ stated for the original instrument by the manufacturer. Total particle number concentrations are determined by the CPCs with different lower threshold diameters. The difference $(\Delta N)$ between the number concentrations of the two CPCs is an indicator of freshly formed particles. The first CPC (Fig. 3, no. 7) measures the number concentration of particles with diameters between 11 and $2 \mu \mathrm{m}\left(N_{11}\right)$, and the second one (Fig. 3, no. 8) measures the concentration of particles in the range between $18 \mathrm{~nm}$ and $2 \mu \mathrm{m}\left(N_{18}\right)$. The aerosol volume flow rate through the CPCs was increased from originally $0.10 \mathrm{~L} \mathrm{~min}^{-1}$ to $0.16 \mathrm{~L} \mathrm{~min}^{-1}$ in order to decrease the response time of the CPCs. The increased volume flow rates through the CPCs led to an increasing lower threshold diameter. To counteract this effect and to derive two different lower threshold diameters, temperature differences between the saturator and condenser inside the CPCs were individually increased using software commands. In order to reach even lower threshold diame- ters, both CPCs were modified again after the test campaign. Now it is possible to detect particles with a diameter of $6 \mathrm{~nm}$ from the first CPC. The OPC (Fig. 3, no. 9) runs with its original pump system and an airflow of $2.83 \mathrm{~L} \mathrm{~min}^{-1}$. The OPC yields the particle number concentrations in six particle size channels from about 0.3 to $10 \mu \mathrm{m}$ particle diameter. The ALADINA aerosol inlet is a $36 \mathrm{~cm}$ long, 3/16", straight stainless steel tube. The sampling line downstream the inlet is made of flexible conductive tubing, in total $24 \mathrm{~cm}$ long, $1 / 4$ ", for the OPC and $28 \mathrm{~cm}$ long, $1 / 4$ " and $3 \mathrm{~mm}$, for the CPCs. Two metal y pieces sequentially split the flow between the OPC and the CPCs. The ALADINA aerosol inlet system sampling efficiency is dominated by two major particle processes (Baron and Willeke, 2001): diffusional losses for particles with diameters of a few nanometres and aspiration enhancement for particles with diameters of a few micrometres. Both can be well estimated using empirical equations given in Baron and Willeke (2001). The ALADINA aerosol inlet is neither isokinetic (TAS $=25.0$ and $v_{\text {sampling }}=8.8 \mathrm{~m} \mathrm{~s}^{-1}$ ) nor isoaxial (mostly in the range of $\pm 20^{\circ}$ ). The limited size and weight prohibited a more complex isokinetic flow system. Effects caused by the non-isoaxial sampling are minimised using rounded inlet lips. Due to the non-isokinetic sampling, particles with several micrometre diameters can be enhanced in the total number concentration by a factor of up to 3 . However, $1 \mu \mathrm{m}$ particles experience only an enhancement of $7 \%$. Particle losses due to diffusion are $17 \%$ for $10 \mathrm{~nm}$ particles and much smaller for larger particles. Thus, the ALADINA aerosol inlet system has a sampling efficiency in the narrow range of 83 to $106 \%$ for Aitken and accumulation mode particles (10-1000 nm diameters).

\subsection{Meteorological sensors and data acquisition}

The meteorological sensor package, mounted at the front of the aircraft (Fig. 2), was designed and integrated by the Environmental Physics group of the Eberhard Karls University of Tübingen (EKUT). It contains a full thermodynamic sensor package with an output of the three-dimensional wind vector, barometric pressure, water vapour content and temperature. In order to measure the three-dimensional wind vector, several sensors are involved: the IMU/GPS system IG$500 \mathrm{~N}$ by SBG systems delivers information about altitude and velocity in the geodetic coordinate system. A five-hole probe designed at the Institute of Fluid Dynamics at the Technische Universität Braunschweig measures the airflow angle and true airspeed. Details about the calibration strategy and airflow retrieval from the five-hole probe, as it is performed in the ALADINA system, are given in Wildmann et al. (2014b). The calculation of the wind vector from all single measurements is described in van den Kroonenberg et al. (2008). With this technique, wind fluctuation of up to $30 \mathrm{~Hz}$ can be resolved and the total accuracy of the wind speed measurement was estimated to be approximately $0.5 \mathrm{~m} \mathrm{~s}^{-1}$ (van den Kroonenberg et al., 2008). The temperature is si- 


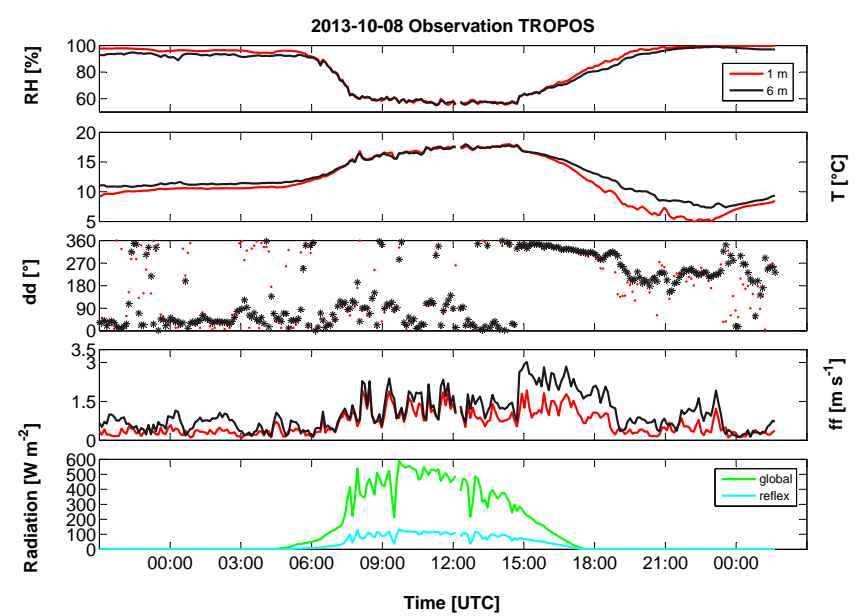

Figure 6. Meteorological parameters at the research site in Melpitz on 8 October 2013. The depicted time range is from 00:00 to 23:50 UTC with 5 min intervals. The data contain measurements of relative humidity $(\mathrm{RH})$, temperature $(T)$, wind direction (dd) and wind speed (ff) in the height of $1 \mathrm{~m}$ (red line, red stars) and $6 \mathrm{~m}$ (black line, black dots) above ground. Further global solar radiance (green line) and reflected global radiation (blue line) are recorded in the short-wave range.

multaneously measured by two fast response sensors: a thermocouple and a fine wire platinum resistance thermometer which are described in detail in Wildmann et al. (2013). A relative humidity sensor of type P14 Rapid (Wildmann et al., 2014c) by Innovative Sensor Technology is used as a small and light-weight solution to measure the water vapour content of the air. The sensor has a specified time response of $1.5 \mathrm{~s}$. Careful post-processing, as presented in Wildmann et al. (2013), is applied and allows a frequency resolution of up to $3 \mathrm{~Hz}$ in the current setup. The central data acquisition system is the airborne meteorological on-board computer (AMOC) that was developed by EKUT in cooperation with the University of Applied Sciences Ostwestfalen-Lippe. All the above-described sensors, including the aerosol instrumentation, are connected to AMOC. Input channels are processed and stored to a secure digital memory card at a sampling rate of $100 \mathrm{~Hz}$. In addition, data transfer through a $2.4 \mathrm{GHz}$ telemetry downlink allows real-time monitoring of sensor data at a ground station computer with a rate of $1 \mathrm{~Hz}$.

\subsection{Unmanned research aircraft MASC}

For additional information about turbulence within the atmospheric boundary layer and to obtain a three-dimensional picture of atmospheric processes, a second unmanned research aircraft MASC (Wildmann et al., 2014a) was operated during the first test campaign simultaneously with ALADINA. MASC was developed at the EKUT and carries the same meteorological sensors as ALADINA. Depending on battery and payload, MASC has a take-off weight of $5.0-7.0 \mathrm{~kg}$ and

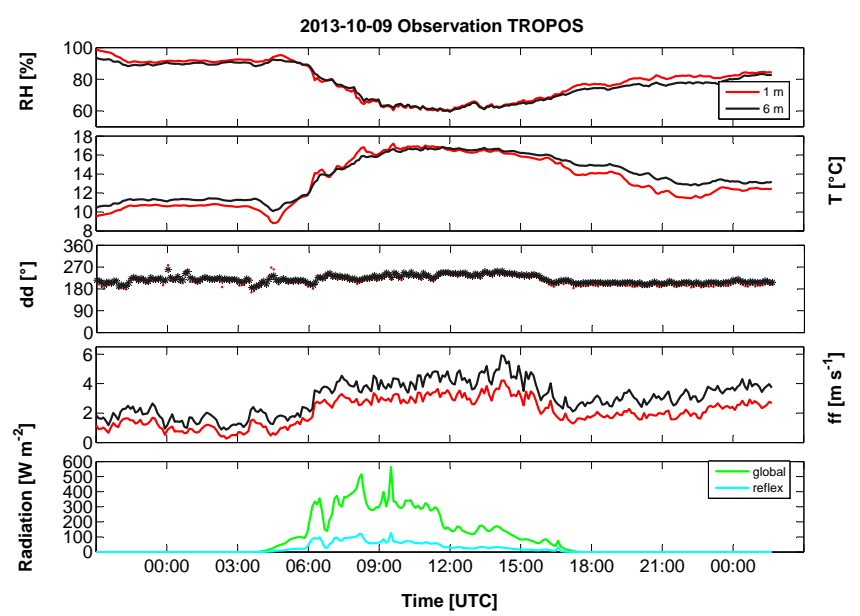

Figure 7. Same as Fig. 6 but on 9 October 2013.

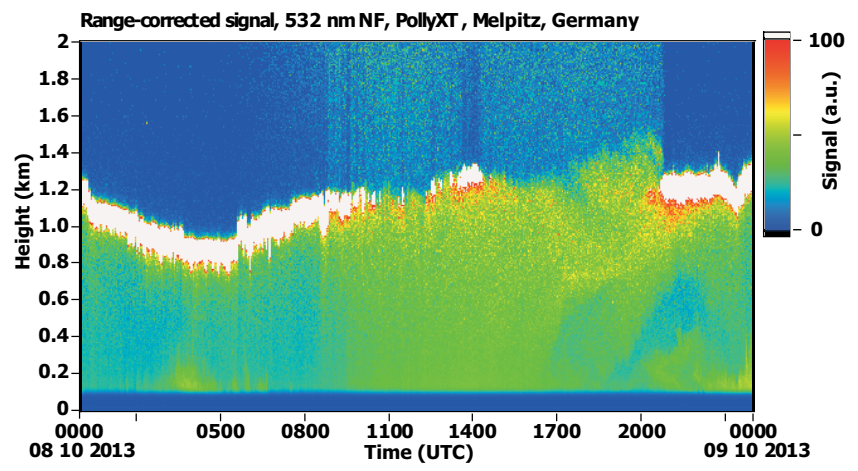

Figure 8. Lidar POLLY ${ }^{\mathrm{XT}}$ measurements (532 nm backscatter signal) in Melpitz on 8 October 2013.

a wingspan between 2.6 and $3.4 \mathrm{~m}$. It has payload capabilities of up to $1.5 \mathrm{~kg}$. An electrical propulsion provides a maximum flight endurance of $60 \mathrm{~min}$. Launching is realised by a bungee rope on flat surfaces. A safety pilot is responsible for take-off and landing. Once in the air, the aircraft is controlled by autopilot ROCS (see Sect. 2.1) with a cruising speed of $25 \mathrm{~m} \mathrm{~s}^{-1}$. Furthermore, the same data acquisition is used in order to derive meteorological parameters. Turbulent fluxes can be obtained in conditions of quasi-stationarity by horizontal flight legs at different altitudes. To obtain statistically relevant data, an average length of at least $1 \mathrm{~km}$ is evaluated for each altitude.

\section{First field application}

\subsection{Measurement site and experiment}

A feasibility study and test of ALADINA performance were conducted at the research station of TROPOS in Melpitz on 8 and 9 October 2013. The site is settled $41 \mathrm{~km}$ northeast of Leipzig, Germany. It is built on a flat meadow and 


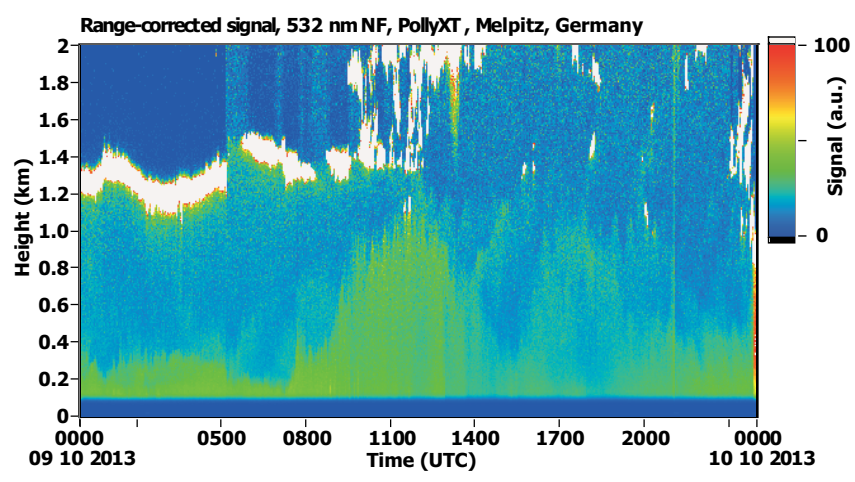

Figure 9. Lidar POLLY ${ }^{\mathrm{XT}}$ measurements (532 nm backscatter signal) in Melpitz on 9 October 2013.

surrounded by agricultural land (Spindler et al., 2013). The surface is smooth and meets the requirements for take-off and landing of the aircraft. Air masses are influenced by industrial and agricultural pollution due to the proximity to Leipzig and due to its surrounding of grass, crop land and woods. The measurement site is qualified for networks like European Monitoring and Evaluation Programme and Aerosols, Clouds, and Trace gases Research InfraStructure Network. Ground-based instruments are used for long-term monitoring in Melpitz. In addition to meteorological parameters, gas concentrations (for example $\mathrm{O}_{3}, \mathrm{NO}, \mathrm{NO}_{2}$ and $\mathrm{SO}_{2}$ ) and atmospheric aerosols are analysed. Particle number size distributions are measured in a range between 5 and $800 \mathrm{~nm}$ by a twin scanning mobility particle sizer (TSMPS) system (Jaatinen et al., 2009; Wiedensohler et al., 2012). Larger particles are detected by an aerodynamic particle sizer. Scans are performed every $10 \mathrm{~min}$ and offer the possibility to observe the temporal development of the atmospheric aerosol. Apart from this, optical instruments detect scattering and absorption coefficients in order to investigate the optical particle properties. The portable 3+2 Raman lidar POLLY ${ }^{\mathrm{XT}}$ (Althausen et al., 2009) was operated at the same time in Melpitz. The data set obtained during the field campaign is used in order to describe the boundary layer development. Previous studies reveal that the station offers great potential for detecting formation mechanisms of ultrafine particles. New particle formation has been mostly observed during spring and summer with particle size distributions increasing from sunrise to noon (Birmili and Wiedensohler, 2000; Birmili et al., 2001). Jaatinen et al. (2009) investigated new particle formation events at three different European sites including Melpitz. Long-term measurements for 2 years (July 2003June 2005) show nucleation events depending on seasons. Operational data imply that $26 \%$ of all measurement days contain events with new particle formation. Formation rates of up to $4.6 \mathrm{~cm}^{-3} \mathrm{~s}^{-1}$ in polluted air masses were detected. Furthermore, a mean growth rate of $6.1 \mathrm{~nm} \mathrm{~h}^{-1}$ was determined.
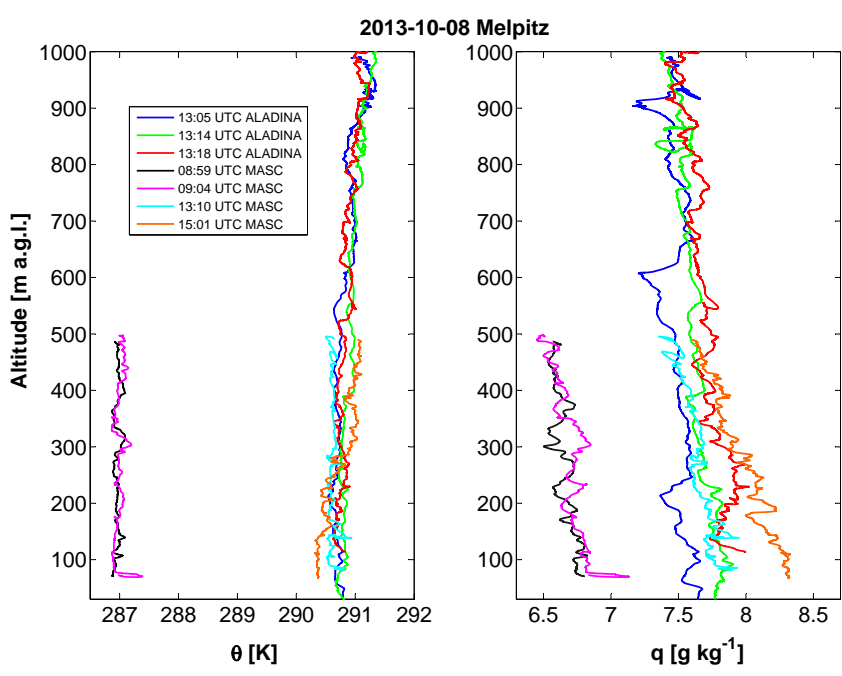

Figure 10. Vertical profiles of (a) potential temperature $\theta$ and (b) water vapour mixing ratio $q$ measured with MASC and ALADINA in Melpitz on 8 October 2013.

ALADINA was operated during three measurement flights in October 2013. Due to technical problems during the first flight, only the data sets obtained during the second and third flight are analysed here. Flight 2 lasted from 13:05 to 13:35 UTC on 8 October 2013. The measurement period of flight 3 took place from 08:26 to 08:58 UTC on 9 October 2013. Altogether, it was possible to obtain 14 vertical profiles with varying vertical extent $(0-1000 \mathrm{~m}, 100-500 \mathrm{~m}$ or less maximum altitude). During the test campaign, combined flights with the two research aircraft ALADINA and MASC were performed. Each flight consisted of several vertical profiles from the surface up to $1000 \mathrm{~m}$ and horizontal legs at various altitudes to investigate layers of enhanced aerosol concentrations and to observe the horizontal distribution of atmospheric aerosols. The best strategy proved to be vertical profiling of ALADINA to catch the development of the ABL and to observe the vertical distribution of aerosols, while MASC performed measurements of turbulent fluxes at the interesting altitudes (for example below and above the inversion or at the layers of enhanced aerosol concentration).

In the following, the general synoptic situation and the meteorological parameters, which were recorded at the observatory during the field campaign, are presented so that one may get an overview of the prevailing weather conditions (Sect. 3.2). Data sets obtained by the lidar POLLY ${ }^{\mathrm{XT}}$ and by vertical soundings with the research aircraft ALADINA and MASC are discussed in the context of the boundary layer development on the 2 measurement days (Sect. 3.3). Aerosol variability, depending on diurnal cycles at the ground, is shown by data sets of a TSMPS and finally compared with the vertical profiling of ALADINA in two different case studies (Sect. 3.4). 

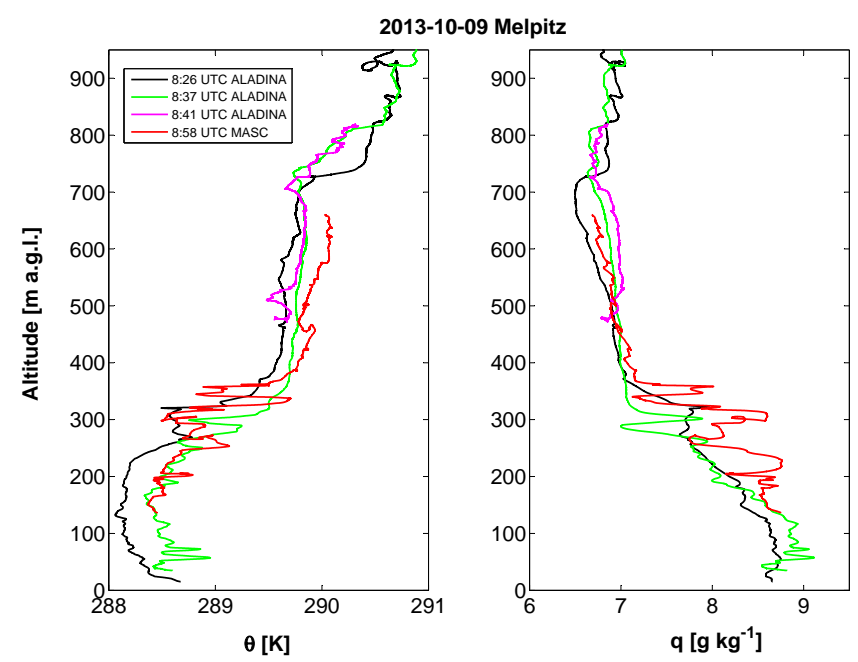

Figure 11. Vertical profiles of (a) potential temperature $\theta$ and (b) water vapour mixing ratio $q$ measured with MASC and ALADINA in Melpitz on 9 October 2013.

\subsection{Synoptic situation}

In this subsection, the weather situation is described in order to obtain information about the contribution of air masses that arrived at the measurement site during the field campaign in October. First, the general weather situation is analysed by the $500 \mathrm{hPa}$ geopotential height, derived from the GFS model is well known in atmospheric measurements and I assume that the community is familiar with using the available sources. The plots were provided in the old version of the manuscript but as suggested from the referees, we have removed them. masses in Melpitz were influenced by a high pressure system at the surface above eastern Germany. In the $500 \mathrm{hPa}$ geopotential level, a trough led to cold advection in the atmosphere. Due to the presence of the high pressure system in the lower part of the atmosphere, the trough has been weakened. The wave system moved eastwards which can be seen by a comparison of the general weather situation with the next day. On 9 October at 08:00 UTC, central Europe was still influenced by a high pressure system at the surface. The trough, which was developing over the Atlantic Ocean in northern Europe, has been settled further to Great Britain. All in all, the weather situation in Germany was rather stable. Back trajectories indicate the source and transport of air masses and were generated by using the NOAA HYSPLIT model (Draxler and Rolph, 2014; Rolph, 2014). In this case, we used the back trajectories in the heights of 500, 1000 and $1500 \mathrm{~m}$ in order to describe their origin and long-transport within the ABL. Analysis of back trajectories reveal the origin of air masses over the Atlantic Ocean. Furthermore, air masses were transported south-west over the northern part of Great Britain and western part of Germany before reaching the research site in Melpitz on 9 October at 08:00 UTC. In particular, the back trajectory of $500 \mathrm{~m}$ showed a longer

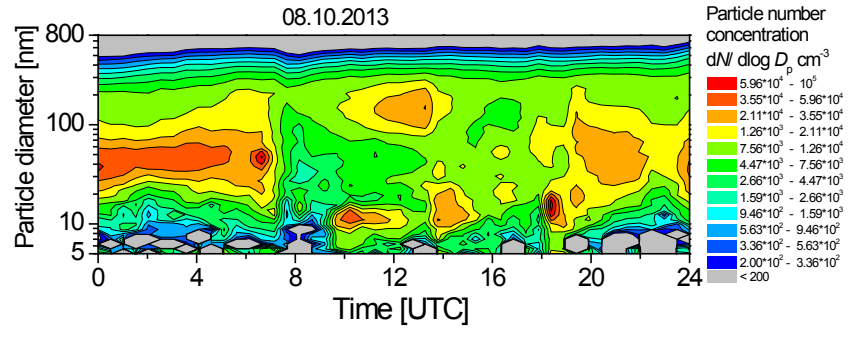

Figure 12. Aerosol number concentration measured with a TSMPS in Melpitz on 8 October 2013.

residence time of 2 days over the eastern part of Germany. However, we assume rather clean air with low concentrations of atmospheric aerosols, because the air masses were mainly influenced by marine environmental conditions. In order to describe the detailed weather situation on-site, we use the meteorological data that were measured continuously by a weather mast at the research station at 1 and $6 \mathrm{~m}$ height above the ground during the flight period. On 8 October (Fig. 6), the temperature ranged at $1 \mathrm{~m}$ level was between $4.9^{\circ} \mathrm{C}$ at $22: 10$ UTC and $18^{\circ} \mathrm{C}$ at 13:55 UTC. The relative humidity reached a maximum value of $99 \%$ in the morning and in the evening at 19:40 UTC. Nevertheless, no rain was measured by the sensor. The pressure decreases continuously from $1017 \mathrm{hPa}$ to $1013 \mathrm{hPa}$ during the day. The main wind direction is northeast but the wind changed from north to south-west in the afternoon. The maximum wind speed of $3 \mathrm{~m} \mathrm{~s}^{-1}$ was detected $6 \mathrm{~m}$ above the ground at 14:30 UTC. Fluctuations of global radiation values indicate a continuously changing cloud coverage. During the second flight time (13:05-13:35 UTC), the temperature reached values of $16.5-17.6^{\circ} \mathrm{C}$. The relative humidity varied between 55 and $59 \%$ with a pressure of $1014 \mathrm{hPa}$. The wind was weak with a maximum of $1.9 \mathrm{~m} \mathrm{~s}^{-1}$ from the north-east. The global radiation ranged from 448 to $533 \mathrm{~W} \mathrm{~m}^{-2}$. Figure 7 shows the situation for the third flight on 9 October. The pressure decreased further from $1013 \mathrm{hPa}$ to $999 \mathrm{hPa}$ during the day. The temperature reached values up to $17.2^{\circ} \mathrm{C}$ at $10: 05 \mathrm{UTC}$ and a minimum of $8.8^{\circ} \mathrm{C}$ at 06:00 UTC. Again, the humidity showed the dependency on temperature. Maximum values were in the morning and night. During day, the relative humidity reached rather dry conditions of $60 \%$. The wind speed gained up to $4.2 \mathrm{~m} \mathrm{~s}^{-1}$ and the wind direction changed to south-west. During flight time (08:26-08:58 UTC), the pressure was $1009 \mathrm{hPa}$ and the temperature was in a range of $14.3-16.8^{\circ} \mathrm{C}$. The relative humidity was rather constant with values around $73 \%$ and the wind speed reached a maximum of $3.3 \mathrm{~m} \mathrm{~s}^{-1}$ from south to south-west. Further fluctuations of the global radiation are an indicator of a changing cloud coverage. Here, the values of the global radiation were $300-515 \mathrm{~W} \mathrm{~m}^{-2}$ during the third flight of ALADINA. 


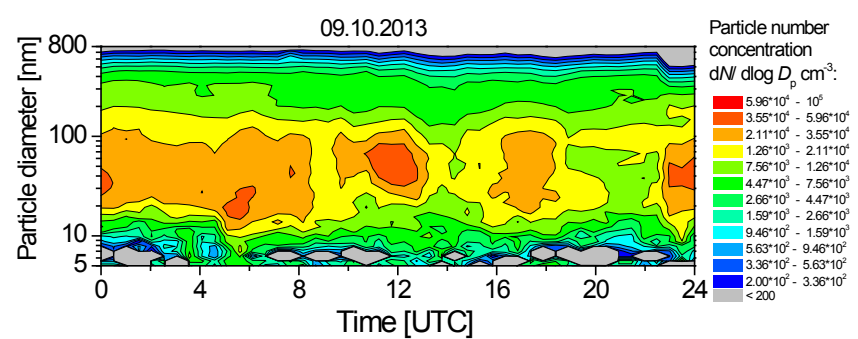

Figure 13. Aerosol number concentration measured with a TSMPS in Melpitz on 9 October 2013.

\subsection{Boundary layer development}

First, the boundary layer development is analysed by the data set of the lidar POLLY ${ }^{\mathrm{XT}}$ (Figs. 8 and 9) that was installed at the same time in Melpitz. Lidar backscatter profiles reveal a boundary layer with pronounced aerosol load indicated by green, yellow and red colours. Figure 8 represents the backscatter signal in the $532 \mathrm{~nm}$ range depending on height from $100 \mathrm{~m}$ up to $2 \mathrm{~km}$ on 8 October 2013. A strong inversion layer was present in the morning, increasing from about $800 \mathrm{~m}$ to $1100 \mathrm{~m}$ altitude. At this height, clouds were formed which can be identified by white structures in the lidar POLLY ${ }^{\mathrm{XT}}$ backscatter profiles. The clouds dissolved during the midday and afternoon. All in all, backscatter signals indicate a well-mixed contribution within the ABL. Figure 10 shows seven vertical profiles of potential temperature $\Theta$ (Fig. 10a) and water vapour mixing ratio (Fig. 10b) obtained by vertical sounding of ALADINA and combined with MASC on 8 October. The first two profiles at 08:59 and 09:04 UTC were flown with MASC and demonstrate a wellmixed ABL up to an altitude of $500 \mathrm{~m}$ above ground level. The potential temperature gradient was stable by values of 268.5 to $287.0 \mathrm{~K}$ within the two profiles. Following profiles show a still well mixed ABL with no significant inversion layer. During ALADINA flights at 13:05, 13:14 and 13:18 UTC, the ABL topping inversion was higher than the maximum flight altitude of $1000 \mathrm{~m}$ above ground level. The last profile of MASC at 15:01 UTC indicates a weak inversion at $300 \mathrm{~m}$. On this day, the water vapour mixing ratio obtained by the profiles of both aircraft varies between $6.6 \mathrm{~g} \mathrm{~kg}^{-1}$ and $8.4 \mathrm{~g} \mathrm{~kg}^{-1}$ at the surface and decreasing values with height.

On 9 October, the ABL was composed of two different air masses which can be seen by the backscatter signal in Fig. 9 . Starting from the surface at night, the layer extended to approximately $400 \mathrm{~m}$ above ground level at 08:00 UTC due to solar radiation and therefore given by the exchange of heat fluxes at the surface. During the day, the second layer was still increasing and finally mixed within the ABL at 14:00 UTC in the afternoon. Again, vertical profiles of both UAS are used in order to describe the lower part of the ABL in a range of $0-1000 \mathrm{~m}$ altitude in detail (Fig. 11). Three vertical profiles were flown with ALADINA from 08:26 to 08:41

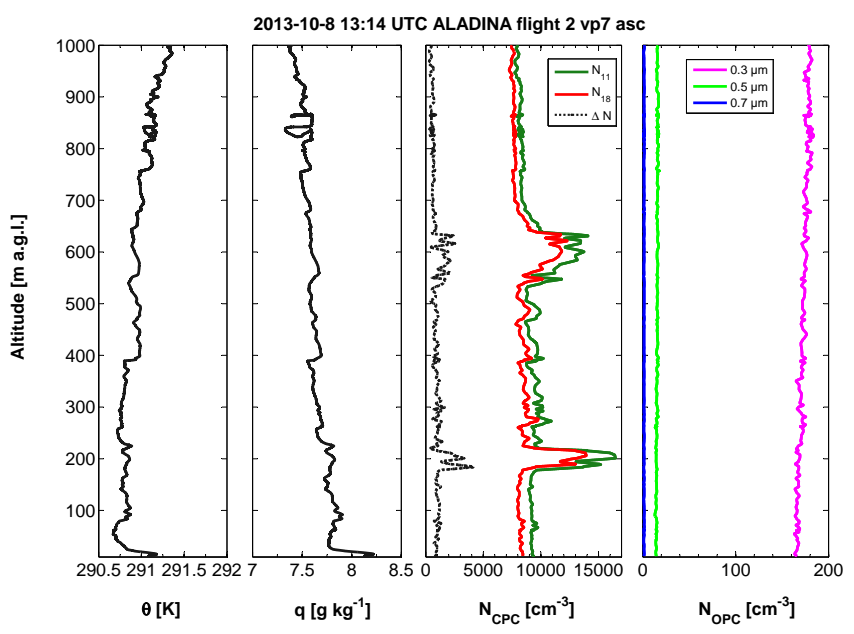

Figure 14. Vertical profiles of (a) potential temperature $\theta$, (b) water vapour mixing ratio $q$, (c) aerosol number concentrations for particle sizes above $11 \mathrm{~nm}\left(N_{11}\right.$, green line), detected with the CPC1 and aerosol number concentrations for particles above $18 \mathrm{~nm}\left(N_{18}\right.$, red line) measured with the CPC2; the difference of both CPCs $(\Delta N$, black dots) and (d) particle number concentrations for particle sizes above $300 \mathrm{~nm}$ (pink line), $500 \mathrm{~nm}$ (bright green line) and $700 \mathrm{~nm}$ (blue line) detected with three OPC channels during flight 2 (ascent) in Melpitz on 8 October 2013 at 13:14 UTC.

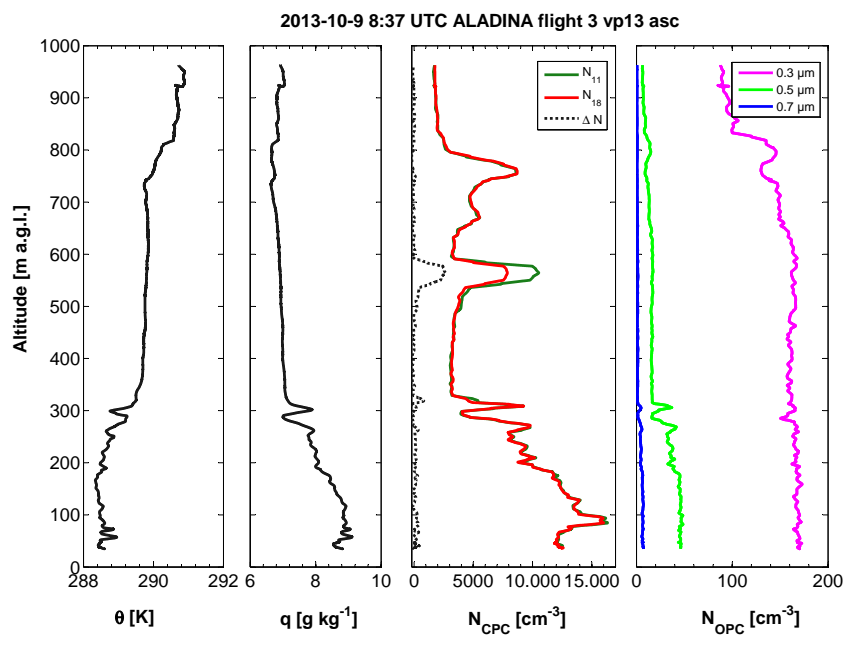

Figure 15. Same as Fig. 15 but during flight 3 (ascent) in Melpitz on 9 October 2013 at 08:37 UTC.

UTC with various vertical extents. Thereafter one vertical profile of MASC ranged from 150 to $650 \mathrm{~m}$ a.g.l. at 08:58 UTC. The water vapour mixing ratio reached values up to $9 \mathrm{~g} \mathrm{~kg}^{-1}$ at the surface and the potential temperature reached a minimum of $288 \mathrm{~K}$ at $150 \mathrm{~m}$ above ground level. Above $350 \mathrm{~m}$ a different layer with other properties, almost neutrally stratified, extended up to $750 \mathrm{~m}$, which can be taken from both parameters. 


\subsection{Aerosol distribution within the ABL}

During the campaign in October 2013, the aerosol number concentration of particles larger than $10 \mathrm{~nm}$ varied between $1500 \mathrm{~cm}^{-3}$ and $35500 \mathrm{~cm}^{-3}$ (Figs. 12 and 13) which is relatively low for continental conditions. However, as mentioned in Sect. 3.2, the origin of air masses was over the Atlantic Ocean. Furthermore, air masses were transported only within the last 2 days over central Europe so that there was a low potential for pollution.

On 8 October the contour plot obtained by the TSMPS data (Fig. 12) shows a significant decrease of the number concentrations between less than 1600 and $4470 \mathrm{~cm}^{-3}$ within the developing boundary layer around 07:00 UTC. At 10:00 UTC, an increase of particle number concentrations with a diameter of about $10 \mathrm{~nm}$ was observed and meets a maximum of $6000 \mathrm{~cm}^{-3}$. These small particles were formed due to new particle formation. At 11:00 UTC, a particle burst of aerosols with a diameter range of 100 to $200 \mathrm{~nm}$ occurred. After 12:00 UTC the picture appears even more variable. NPF stopped and started again but with a broader burst. This is probably due to variations in the global radiation by increasing coverage of cumulus clouds (see Fig. 6). However, this day is not a classical new particle formation day with a continuous growth of the small particles; rather, they appear as small bursts. These ground-based measurements fit well with the measured profiles of ALADINA. At the ground, the mean total aerosol number concentration of the small particles was $10000 \pm 2000 \mathrm{~cm}^{-3}$ and constant to a height around $180 \mathrm{~m}$ (Fig. 14c). Between 180 and $240 \mathrm{~m}$ altitude, a layer of significantly enhanced aerosol was observed. The maximum of the CPC1 was $N_{11}=17000 \pm 3400 \mathrm{~cm}^{-3}$ and the CPC2 detected a maximum of $N_{18}=14500 \pm 2900 \mathrm{~cm}^{-3}$. A second layer of enhanced aerosol load was detected in 550 to $620 \mathrm{~m}$ altitude. Above this, the total aerosol number concentration decrease to the same amount as measured at the ground. All in all, a continuous difference between CPC 1 and CPC 2 was observed by the vertical distribution of $\Delta N$, meaning there was a certain number of particles in the size range between 11 and $18 \mathrm{~nm}$. Nevertheless, the most dominant differences are in the two distinct aerosol layers.

On the next day ( 9 October), no sharp jump of number concentrations of small particles with a diameter of $10 \mathrm{~nm}$ were observed by the TSMPS at the ground (Fig. 13). However, the total aerosol number concentration increased and maximum values of $35500 \mathrm{~cm}^{-3}$ with a diameter range of 30 to $100 \mathrm{~nm}$ occurred at 11:30 UTC. Compared to the day before, the variability of atmospheric aerosols was more homogeneous. This is consistent with the results of the third flight of ALADINA at 08:37 UTC. The number concentration of the small particles increased (compared with the previous day) at the ground to a maximum of $12500 \pm 2500 \mathrm{~cm}^{-3}$ and identically measured by both CPCs (Fig. 15c). Up to a height of $100 \mathrm{~m}$, the total aerosol number concentration increased to a maximum of $16500 \pm 3300 \mathrm{~cm}^{-3}$ and afterwards de- creased until reaching the inversion at $320 \mathrm{~m}$ with a minimum of $4000 \pm 800 \mathrm{~cm}^{-3}$. Above the inversion and up to a level of around $480 \mathrm{~m}$ altitude, the aerosol distribution was rather constant. However, at the height of 480 to $620 \mathrm{~m}$, the total aerosol number concentration rapidly increased to $N_{18}=$ $8000 \pm 1600 \mathrm{~cm}^{-3}$ and $N_{11}=11000 \pm 2200 \mathrm{~cm}^{-3}$. This difference corresponds to $\Delta N=3000 \pm 600 \mathrm{~cm}^{-3}$ and thus to a particle burst, here without any obvious connection to the stratification of the ABL. In the altitude between 620 and $1000 \mathrm{~m}$, the total aerosol number concentration decreased again and both CPCs detected the same amount. All in all, a high dependency of atmospheric aerosols on the atmospheric stratification was observed apart from the particle burst events.

According to the time series of the backscatter lidar POLLY ${ }^{\mathrm{XT}}$ (Fig. 8), the ABL altitude increased from about 800 to about $1100 \mathrm{~m}$ above the ground during the morning transition on 8 October. The aerosol load appears to be rather well mixed within the ABL because no strong layers could be identified from the colour scheme. On 9 October, an increase of the ABL altitude from about 1000 to $1200 \mathrm{~m}$ was also observed (Fig. 9). The aerosol distribution shows a layer of clearly enhanced aerosol load at an altitude below $400 \mathrm{~m}$. These features are in agreement with the observations of ALADINA. In Figs. 14d and 15d the profiles of the OPC $0.5 \mu \mathrm{m}$ channel reveal a uniform distribution of aerosols up to $1000 \mathrm{~m}$ on 8 October. In contrast, an enhanced aerosol load in the lowermost $400 \mathrm{~m}$ was observed on 9 October. Both days indicate clean air masses due to the small amount of atmospheric particles with a diameter range of larger than $300 \mathrm{~nm}$. However, for the small particles recorded with the CPCs, there was an additional fine layer structure visible that is not caught by the larger wavelengths of the OPC $(300,500$ and $700 \mathrm{~nm}$ ). On 8 October, layers with enhanced small particle concentration were observed directly above ground at an altitude of 200 to $250 \mathrm{~m}$ and at $600 \mathrm{~m}$. All in all, a high vertical variability of the small-size aerosol concentration were presented (Fig. 14c). On 9 October 2013, the small-size particles were also enhanced in the lowest $320 \mathrm{~m}$. Pronounced peaks of small-size aerosol are found at an altitude of 650 and $780 \mathrm{~m}$. The enhanced aerosol load in the lowest $400 \mathrm{~m}$ was directly related to the ABL conditions. The profile of the potential temperature (Fig. 15a) shows a slightly unstable stratification within the lowermost $400 \mathrm{~m}$. At this altitude, a shallow layer of stably stratified air prevented mixing with higher altitudes. Also, the water vapour mixing ratio was considerably enhanced in the lowest $400 \mathrm{~m}$ (Fig. 15b). From 320 to $870 \mathrm{~m}$ the thermal profile was neutral and then again stable above. The layer of enhanced small-size aerosol concentration at $780 \mathrm{~m}$ coincided with the beginning of the stable stratification. In contrast, the profile of the potential temperature on 8 October revealed an almost neutral, but strongly varying, potential temperature (Fig. 14a). This indicates that air masses of different origin might have been sampled during the ascent of ALADINA in spirals. Again, the layers of 
enhanced small size aerosol concentration (Fig. 14c) coincided with the altitudes where changes in the profile of the potential temperature were observed, enabling or prohibiting mixing processes.

\section{Summary and conclusions}

In this study, the new unmanned research aircraft Carolo P360 "ALADINA" is presented. It was developed for atmospheric boundary layer aerosol research and thus equipped with a small and light $(<2.8 \mathrm{~kg})$ aerosol and meteorological payload. Two CPCs with different threshold diameters (11 and $18 \mathrm{~nm}$ ) offer the possibility to measure total particle number concentrations of freshly formed particles with a response time $t_{10-90 \%}$ of $1.3 \mathrm{~s}$. An OPC records size distributions of larger particles in six channels between 0.3 and $10 \mu \mathrm{m}$. Fast meteorological sensors with a resolution of up to $30 \mathrm{~Hz}$ provide turbulence measurements and thus the possibility to connect atmospheric and aerosol dynamics. After sensor characterisation in the laboratory and in a wind tunnel, a first test campaign was conducted at the GAW station Melpitz (Germany) in October 2013. Typical flight patterns for identifying the vertical distribution of aerosols were flown by vertical profiles from the ground up to an altitude of $1000 \mathrm{~m}$. Additionally, MASC provided measurements of meteorological parameters simultaneously. In this paper, data of two flights with different aerosol conditions were analysed. One flight was performed on 8 October 2013 at 13:14 UTC. On this day, new particle formation was observed at the ground by the TSMPS data. A continuous difference of both CPCs, $\Delta N$, represents a low number concentration of freshly formed particles in the prevailing neutrally stratified ABL. In addition, two significant aerosol layers were present with a maximum of $17000 \pm 3400 \mathrm{~cm}^{-3}$ at 180 and $220 \mathrm{~m}$ altitude and $14000 \pm 2800 \mathrm{~cm}^{-3}$ at 550 to $650 \mathrm{~m}$, in an otherwise well-mixed structure of aerosols in the ABL. During the other flight on 9 October at 08:37 UTC, no particle burst event was detected at the ground, but an internal layer in the atmospheric boundary layer with different aerosol properties was present. From the ground to the inversion at $320 \mathrm{~m}$ altitude, the total number concentration decreased and reached a minimum above the inversion. At a level between 500 and $600 \mathrm{~m}$ altitude, a difference of both CPCs was measured that corresponds to a new particle formation event. The comparison of the ALADINA results with ground-based in situ aerosol instruments and a lidar POLLY ${ }^{\mathrm{XT}}$ gives confidence in the obtained data and in the capability of this new system to record aerosol size distributions with good reliability. After the campaign, one additional original TSI Peltier element was installed to cool the condenser of one CPC and to increase the temperature difference inside the second CPC to achieve two more distinct detection threshold limits $(6$ and $18 \mathrm{~nm}$ ). The potential of this flexible airborne system for new particle formation investigations will be further explored in future follow-up campaigns at the Melpitz observatory. The further technical and scientific development of ALADINA will accompany the follow-up campaigns. The possibility to optionally implement other aerosol instruments (e.g. an aethalometer) is currently under discussion. Future applications will also include the validation of remote-sensingderived aerosol properties.

Acknowledgements. This work is supported by the German Research Foundation (LA 2907/5-1, WI 1449/22-1, BA 1988/14-1). We thank Gerald Lohmann for his contribution to the setup of ALADINA. Thanks go to the aerosol and lidar groups of TROPOS for using the ground-based data of the research station and for organising the radiosonde ascent. A special thanks to Achim Grüner, Chemistry Department, for technical assistance during the campaign. The authors acknowledge Lutz Bretschneider and Philipp Schrapel for their performance as good safety pilots. We thank the local aviation authorities for support with the flight permission. Thanks go to Grant Allen and an anonymous referee for improving the manuscript.

Edited by: G. Phillips

\section{References}

Althausen, D., Engelmann, R., Baars, H., Heese, B., Ansmann, A., Müller, D., and Komppula, M.: Portable Raman Lidar Polly XT for automated profiling of aerosol backscatter, extinction, and depolarization, J. Atmos. Ocean. Tech., 26, 2366-2378, 2009.

Baltensperger, U.: Analysis of aerosols, CHIMIA Int. J. Chem., 51, 686-689, 1997.

Baron, P. A. and Willeke, K.: Aerosol measurements: Principles techniques and applications Wiley, New York, 2001.

Bates, T. S., Quinn, P. K., Johnson, J. E., Corless, A., Brechtel, F. J., Stalin, S. E., Meinig, C., and Burkhart, J. F.: Measurements of atmospheric aerosol vertical distributions above Svalbard, Norway, using unmanned aerial systems (UAS), Atmos. Meas. Tech., 6, 2115-2120, 2013,

http://www.atmos-meas-tech.net/6/2115/2013/.

Bigg, E. K.: A mechanism for the formation of new particles in the atmosphere, Atmos. Res., 43, 2, 129-137, 1997.

Birmili, W., and Wiedensohler, A.: New particle formation in the continental boundary layer: Meteorological and gas phase parameter influence, Geophys. Res. Lett., 27, 3325-3328, 2000.

Birmili, W., Wiedensohler, A., Heintzenberg, J., and Lehmann, K.: Atmospheric particle number size distribution in central Europe: Statistical relations to air masses and meteorology, J. Geophys. Res., 106, 32005-32018, 2001.

Boy, M., Rannik, Ü., Lehtinen, K. E. J., Tarvainen, V., Hakola, H., and Kulmala, M.: Nucleation events in the continental boundary layer: Long-term statistical analyses of aerosol relevant characteristics, J. Geophys. Res., 108, 4667, doi:10.1029/2003JD003838, 2003.

Boy, M., Hellmuth, O., Korhonen, H., Nilsson, E. D., ReVelle, D., Turnipseed, A., Arnold, F., and Kulmala, M.: MALTE - model 
to predict new aerosol formation in the lower troposphere, Atmos. Chem. Phys., 6, 4499-4517, doi:10.5194/acp-6-4499-2006, 2006.

Clarke, A. D., Ahlquist, N. C., Howell, S., and Moore, K.: A miniature optical particle counter for in situ aircraft aerosol research, J. Atmos. Ocean. Tech., 19, 1557-1566, 2002.

Corrigan, C. E., Roberts, G. C., Ramana, M. V., Kim, D., and Ramanathan, V.: Capturing vertical profiles of aerosols and black carbon over the Indian Ocean using autonomous unmanned aerial vehicles, Atmos. Chem. Phys., 8, 737-747, doi:10.5194/acp-8-737-2008, 2008.

Davidson, C. I., Phalen, R. F., and Solomon, P. A.: Airborne particulate matter and human health: a review, Aerosol Sci. Tech., 39, 8, 736-749, doi:10.1080/02786820500191348, 2005.

Draxler, R. R. and Rolph, G. D.: HYSPLIT (HYbrid Single-Particle Lagrangian Integrated Trajectory) Model access via NOAA ARL READY Website, available at: http://ready.arl.noaa.gov/ HYSPLIT.php, last access: 8 October 2013, NOAA Air Resources Laboratory, Silver Spring, MD, 2014.

Doyle, G. J.: Self-nucleation in the sulphuric acid-water system. J. Chem. Phys., 35, 795-799, 1961.

Haala, N., Cramer, M., Weimer, F., and Trittler, M.: Performance test on UAV-based photogrammetric data collection, in: Proceedings of the International Archives of the Photogrammetry, Remote Sensing and Spatial Information Sciences, Zurich, Switzerland, 14-16 September 2011, XXXVIII-1/C22, 7-12, 2011.

Harnisch, F., Gohm, A., Fix, A., Schnitzhofer, R., Hansel, A., and Neininger, B.: Spatial distribution of aerosols in the Inn Valley atmosphere during wintertime, Meteorol. Atmos. Phys., 103, 14, 223-235, 2009.

Hermann, M. and Wiedensohler, A.: Counting efficiency of condensation particle counters at low-pressures with illustrative data from the upper troposphere, J. Aerosol Sci. 32, 975-991, 2001.

Hellmuth, O.: Columnar modelling of nucleation burst evolution in the convective boundary layer - first results from a feasibility study Part III: Preliminary results on physicochemical model performance using two "clean air mass" reference scenarios, Atmos. Chem. Phys., 6, 4231-4251, doi:10.5194/acp-6-4231-2006, 2006.

Illingworth, S. M., Allen, G., Percival, C., Hollingsworth, P., Gallagher, M. W., Ricketts, R., Hayes, H., Ladosz, P., Crawley, D., and Roberts, G.: Measurement of boundary layer ozone concentrations on-board a Skywalker Unmanned Aerial Vehicle, Atmos. Sci. Lett., 15, 4, 252-258, doi:10.1002/asl2.496, 2014.

Jaatinen, A., Hamed, A., Joutsensaari, J., Mikkonen, S., Birmili, W., Wehner, B., Spindler, G., Wiedensohler, A., Decesari, S., Mircea, M., Faccini, M. C., Junninen, H., Kulmala, M., Lehtinen, K. E. J., and Laaksonen, A.: A comparison of new particle formation events in the boundary layer at three different sites in Europe, Boreal Environ. Res., 14, 481-498, 2009.

Kannosto, J., Virtanen, A., Lemmetty, M., Mäkelä, J. M., Keskinen, J., Junninen, H., Hussein, T., Aalto, P., and Kulmala, M.: Mode resolved density of atmospheric aerosol particles, Atmos. Chem. Phys., 8, 5327-5337, doi:10.5194/acp-8-5327-2008, 2008.

Kulmala, M., Pirjola, L., and Mäkelä, J.M., and Jyrki, M.: Stable sulphate clusters as a source of new atmospheric particles, Nature, 404, 6773, 66-69, 2000.

Kulmala, M., Vehkamäki, H., Petäjä, T., Dal Maso, M., Lauri, A., Kerminen, V.-M., Birmili, W., and McMurry, P. H.: Formation and growth rates of ultrafine atmospheric particles: a review of observations, Aerosol Sci., 35, 143-176, 2004.

Nilsson, E. D., Rannik, Ü., Kulmala, M., Buzorius, G., and O'Dowd, C. D.: Effects of continental boundary layer evolution, convection, turbulence and entrainment, on aerosol formation, Tellus, 53, 441-461, 2001.

O’Dowd, C. D., Yoon, Y. J., Junkermann, W., Aalto, P., Kulmala, M., Lihavainen, H., and Viisanen, Y.: Airborne measurements of nucleation mode particles II: boreal forest nucleation events, Atmos. Chem. Phys., 9, 937-944, doi:10.5194/acp-9-937-2009, 2009.

Raes, F., Saltelli, A., and Van Dingenen, R.: Modelling formation and growth of $\mathrm{H}_{2} \mathrm{SO}_{4}-\mathrm{H}_{2} \mathrm{O}$ aerosols: Uncertainty analysis and experimental evaluation, J. Aerosol Sci., 23, 759-771, 1992.

Ramanathan, V., Crutzen, P. J., Kiehl, J. T., and Rosenfeld, D.: Aerosols, climate, and the hydrological cycle, Science, 294, 2119-2124, 2001.

Rolph, G. D.: Real-time Environmental Applications and Display sYstem (READY) Website, available at: http://ready.arl.noaa. gov, access date on 8 October 2013, NOAA Air Resources Laboratory, Silver Spring, MD, 2014.

Scholtz, A., Kaschwich, C., Krüger, T., Kufieta, K., Schnetter, P., Wilkens, C.-S., and Vörsmann P.: Development of a new multipurpose UAS for scientific application, in: Proceedings of the International Conference on Unmanned Aerial Vehicle in Geomatics (UAV-g), Zurich, Switzerland, 14-16 September 2011, XXXVIII-1/C22, 149-154, 2011.

Siebert, H., Stratmann, F., and Wehner, B.: First observations of increased ultrafine particle number concentrations near the inversion of a continental planetary boundary layer and its relation to ground-based measurements, Geophys. Res. Lett., 31, L09102, doi:10.1029/2003GL019086, 2004.

Siebert, H., Wehner, B., Hellmuth, O., Stratmann, F., Boy, M., and Kulmala, M.: New particle formation in connection with a nocturnal low-level jet: Observations and modeling results, Geophys. Res. Lett., 34, L16822, doi:10.1029/2007GL029891, 2007.

Sorribas, M., de la Morena, B. A., Wehner, B., López, J. F., Prats, N., Mogo, S., Wiedensohler, A., and Cachorro, V. E.: On the sub-micron aerosol size distribution in a coastal-rural site at El Arenosillo Station (SW - Spain), Atmos. Chem. Phys., 11, 11185-11206, doi:10.5194/acp-11-11185-2011, 2011.

Spindler G., Grüner A., Müller K., Schlimper S., and Herrmann H.: Long-term size-segregated particle (PM10, PM2.5, PM1) characterization study at Melpitz-influence of air mass inflow, weather conditions and season, J. Atmos. Chem., 70, 2, 165-195, 2013.

Spracklen, D. V., Carslaw, K. S., Kulmala, M., Kerminen, V.-M., Sihto, S.-L., Riipinen, I., Merikanto, J., Mann, G. W., Chipperfield, M. P., Wiedensohler, A., Birmili, W., and Lihavainen, H.: Contribution of particle formation to global cloud condensation nuclei concentrations, J. Geophys. Res,. 35, L06808, doi:10.1029/2007GL033038, 2008.

Stieb, D. M., Judek, S., and Burnett, R. T.: Meta-analysis of timeseries studies of air pollution and morality: effects of gases and particles and their influence of cause of death, age and season, J. Air Manage. Asso., 52, 470-484, 2002.

Stratmann, F., Siebert, H., Spindler, G., Wehner, B., Althausen, D., Heintzenberg, J., Hellmuth, O., Rinke, R., Schmieder, U., Seidel, C., Tuch, T., Uhrner, U., Wiedensohler, A., Wandinger, U., Wendisch, M., Schell, D., and Stohl, A.: New-particle forma- 
tion events in a continental boundary layer: first results from the SATURN experiment, Atmos. Chem. Phys., 3, 1445-1459, doi:10.5194/acp-3-1445-2003, 2003.

Thomas, R. M., Lehmann, K., Nguyen, H., Jackson, D. L., Wolfe, D., and Ramanathan, V.: Measurement of turbulent water vapor fluxes using a lightweight unmanned aerial vehicle system, Atmos. Meas. Tech., 5, 243-257, doi:10.5194/amt-5-243-2012, 2012.

van den Kroonenberg, A., Martin, T., Buschmann, M., Bange, J., and Vörsmann, P.: Measuring the wind vector using the autonomous mini aerial vehicle $\mathrm{M}^{2} \mathrm{AV}$, J. Atmos. Ocean. Tech., 25, 1969-1982, 2008.

Vana, M., Kulmala, M., Dal Maso, M., Hõrrak, U., and Tamm, E.: Comparative study of nucleation mode aerosol particles and intermediate air ions formation events at three sites, J. Geophys. Res., 109, D17201, doi:10.1029/2003JD004413, 2004.

Weber, R. J., Marti, J. J., McMurry, P. H., Eisele, F. L., Tanner, D. J., and Jefferson, A.: Measurements of new particle formation and ultrafine particle growth rates at clean continental site, J. Geophys. Res., 102, 4375-4385, 1997.

Wehner, B., Siebert, H., Stratmann, F., Tuch, T., Wiedensohler, A., Petäjä, T., Dal Maso, M., and Kulmala, M.: Horizontal homogeneity and vertical extent of new particle formation events, Tellus B, 59, 362-371, 2007.

Wehner, B., Siebert, H., Ansmann, A., Ditas, F., Seifert, P., Stratmann, F., Wiedensohler, A., Apituley, A., Shaw, R. A., Manninen, H. E., and Kulmala, M.: Observations of turbulence-induced new particle formation in the residual layer, Atmos. Chem. Phys., 10, 4319-4330, doi:10.5194/acp-10-4319-2010, 2010.
Wiedensohler, A., Covert, D. S., Swietlicki, E., Aalto, P., Heintzenberg, J., and Leck, C.: Occurrence of an ultrafine particle mode less than $20 \mathrm{~nm}$ diameter in the marine boundary layer during Arctic summer and autumn, Tellus, 48, 213-222, 1996.

Wiedensohler, A., Birmili, W., Nowak, A., Sonntag, A., Weinhold, K., Merkel, M., Wehner, B., Tuch, T., Pfeifer, S., Fiebig, M., and others: Mobility particle size spectrometers: harmonization of technical standards and data structure to facilitate high quality long-term observations of atmospheric particle number size distributions, Atmos. Meas. Tech., 5, 657-685, 2012, http://www.atmos-meas-tech.net/5/657/2012/.

Wildmann, N., Mauz, M., and Bange, J.: Two fast temperature sensors for probing of the atmospheric boundary layer using small remotely piloted aircraft (RPA), Atmos. Meas. Tech., 6, 8, 21012113, doi:10.5194/amt-6-2101-2013, 2013.

Wildmann, N., Hofsäß, M., Weimer, F., Joos, A., and Bange, J.: MASC-a small remotely piloted aircraft (RPA) for wind energy research, Adv. Sci. Res., 11, 55-61, doi:10.5194/asr-11-55-2014, 2014a.

Wildmann, N., Ravi, S., and Bange, J.: Towards higher accuracy and better frequency response with standard multi-hole probes in turbulence measurements with remotely piloted aircraft (RPA), Atmos. Meas. Tech., 7, 1027-1041, doi:10.5194/amt-7-1027-2014, 2014b.

Wildmann, N. and Kaufmann, F., and Bange, J.: An inverse modelling approach for frequency response correction of capacitive humidity sensors in ABL research with small unmanned aircraft, Atmos. Meas. Tech., 7, 4407-4438, doi:10.5194/amtd-7-44072014, 2014c. 